\title{
INFORMAL LAND TITLES: SNOWDEN V BAKER (1844)
}

\author{
Bruce Kercher
}

Snowden v Baker (1844) concerned the judicial recognition of informal land titles. This article compares the treatment of this broad question in Newfoundland and New South Wales, with Snowden v Baker.

In Newfoundland and New South Wales, informal titles gained legal recognition. This happened in Newfoundland through judicial creativity, including statutory interpretation. In New South Wales, the formal law was applied more strictly, but was softened when commissioners were appointed to assess whether Crown discretion should be exercised in favour of those dispossessed due to informality.

Both methods were used in New Zealand, where the informal titles of British settlers derived from sales by Māori land owners. Titles purchased from Māori owners were declared null and void unless based on Crown grants. As in New South Wales, commissioners were appointed to advise whether such grants should be made. In Snowden v Baker, Martin CJ used statutory interpretation to take a further step, by holding that titles derived from Māori sales had a contingent validity until affirmed or denied by the Crown.

The aim of this article is to place Snowden $v$ Baker (1844) $)^{1}$ in an imperial context, by comparing it with the case law of two other colonies, Newfoundland and New South Wales. This is based on an earlier book chapter about land law in those two colonies, ${ }^{2}$ which attempted to compare the decisions of Francis Forbes, Chief Justice in both places. This article attempts to expand the comparison by drawing in New Zealand. The principal question is how were informal views of land

* Emeritus Professor of Law, Macquarie University.

1 Snowden v Baker, Supreme Court Auckland, 20 January 1844 per Martin CJ, reported in Daily Southern Cross (Auckland, 27 January 1844) at 2.

2 B Kercher and J Young "Formal and Informal Law in Two New Lands: Land Law in Newfoundland and New South Wales under Francis Forbes" in Christopher English (ed) Essays in the History of Canadian Law: Volume IX: Two Islands, Newfoundland and Prince Edward Island (University of Toronto Press, Toronto, 2005) 147. 
holding treated in the courts? Was there a clash between informal and formal views of law, and if so, how was it resolved?

Before examining the operation of informal law in Newfoundland and New South Wales, it is necessary to give a brief statement of the facts in Snowden v Baker. On 16 May 1840, Snowden entered into an agreement with Baker to sell him some pieces of land at Wangaroa, as well as certain trees growing on another piece of land. Baker entered into possession of the land immediately after the execution of the agreement, and upon paying half of the purchase price. Snowden's title was not derived from the Crown, but from a sale to him by the original Māori holders of the land. The problem for the parties was that four months earlier, Governor Gipps of New South Wales had declared that all titles to land in New Zealand were null and void except those derived from the Crown. There was provision, however, for some recognition of purchases from Māori before the date of the proclamation. This was later confirmed if not clarified by an Act of the New South Wales legislature, and later again by the New Zealand legislature.

The vendor Snowden was the plaintiff, seeking the recovery of $£ 500$, the remainder of the purchase price of $£ 1,000$. Was Baker required to pay the balance of the price? More broadly, what was it that Snowden had purported to sell to Baker? The parties obviously thought that a title derived from Māori vendors was valuable, but what did the law say?

\section{INFORMAL LAW}

Twenty five years ago, an American legal historian, Hendrik Hartog, wrote an influential article called Pigs and Positivism. ${ }^{3}$ He was interested in the unruly behaviour of the pig keepers of New York. When pigs roamed around the streets, they caused disease and accidents. Regulations were passed repeatedly in an attempt to restrict the actions of their owners, but the owners repeatedly refused to obey them. Was this simply an instance of law breaking, people taking advantage of a lack of regulatory enforcement, or was something else at work? Hartog argued that the pig keepers acted through a belief that their actions were somehow lawful. By resisting formal law, they were asserting their own informal views of law.

Hartog was not the only person to make an argument of this kind. In a series of articles, ${ }^{4} \mathrm{EP}$ Thompson made similar analyses of English law breakers. He discussed food rioters, smugglers, and gleaners among other people. In each case, he argued, the people of England were not merely being disobedient. They were asserting their popular customs by refusing to obey laws which, in some cases, had made those customs unlawful long after they had been established. These people, too, were acting in accordance of their customary views of the law, regardless of the formal law.

3 H Hartog "Pigs and Positivism" (1985) Wisconsin L Rev 899.

4 Posthumously published in EP Thompson Customs in Common (Penguin Books, London, 1991). 
This idea of resistance based on popular conceptions of law is particularly useful in a colonial context. In places such as Newfoundland, New South Wales, and, this paper will argue, New Zealand, the European population had its own ideas of law. Happily, this included the pig keepers of early Sydney. Like their counterparts in New York, they often breached the regulations which sought to restrict their activities. It might not be a surprise that the convict society in Sydney was particularly characterised by law breaking. The governors made orders which sought to restrict the issuing of promissory notes, control the use of convict labour, and regulate the sale of land and much else. Many of these regulations, along with the common law itself, were breached. Even Governor Bligh, the most authoritarian of the New South Wales governors, was unable to enforce many of his regulations. ${ }^{5}$ Ultimately, of course, he was the victim of the greatest example of resistance to law: the military coup which overthrew his administration in 1808.

Of course the most important example of non-state law was that of the indigenous peoples in these three colonies. This paper deals with that only obliquely. Future research might fruitfully compare the formal law's treatment of indigenous and European informal law. That is not the basis of this paper.

Hartog and Thompson raised the possibility of law breaking being based on popular legal ideas, but each of them took only the first step. The next step after that is just as important: what did the courts do when faced with law breaking based on popular conceptions of law? Were there some occasions in which informal law was adopted by the courts? This is just what happened in early New South Wales. Even when there was a direct clash between formal law and popular customs, the courts sometimes elevated informal law upwards. This was not confined to the earliest amateur judges. Some of the trained barristers who later held colonial judicial office in Sydney occasionally did the same. As a result, the law makers of New South Wales sometimes included convicts, officers and traders whose apparently unlawful conduct was based on implicit ideas of law. ${ }^{6}$

We should not to be too romantic about this idea of law breaking based on dissenting popular notions of law. Thompson tended to see heroic impulses in working people, but this impulse was not restricted to them. The officers who overthrew Bligh in 1808 argued, presumably through genuine belief in at least some cases, that they were enforcing the law through their action in obviously breaking it. Nor was law breaking always based on a bona fide belief in the legality of the action. Thieves were sometimes simply thieves, hoping to get away with whatever they could. Many of us break speed limits, not because we think it is lawful, but because we think we will get away with it. And even when people did think their law breaking was justified by some notion of popular customs or beliefs, those beliefs were sometimes abhorrent, such as those behind the killings of native

5 B Kercher "Resistance to Law under Autocracy" (1997) 60 Modern Law Review 779.

6 Ibid. 
people. There seemed to be a genuinely held belief among some people in early New South Wales that Aboriginal lives had less value than those of the colonists. ${ }^{7}$

It is important, then, to look for some evidence that people were attempting to justify their illegal actions by implicit reference to law. Fortunately for this paper, that is particularly easy in the case of informal land holding. In the three colonies which studied in this paper, Newfoundland, New South Wales and New Zealand, people sometimes held land contrary to expressed government policies or formal law. We know that these land holders believed that their titles were in some sense valid: they spent money on improving the land or on purchasing it. That would have been unlikely if they felt they were merely trespassers. It is not merely a romantic fiction to see these cases as examples of the activities described by Hartog and Thompson.

Land law is especially useful to a study of informal law in colonial societies. Unlike in England, colonial land law was not a matter dominated by the rights of the gentry and aristocracy, but concerned a broad range of settlers who held land mainly for the generation of income. There were other social benefits to holding land in the colonies, but these benefits were very different from those in England. Colonial land holding was based on entirely different assumptions, different approaches to the utility of land. We should not be surprised to find that those differences led to clashes between colonial customs and the received laws of England.

Many legal historians have found that colonial law quite often differed markedly from that of England due to different social and economic conditions. ${ }^{8}$ That was nowhere more evident than in land law.

\section{INFORMAL LAND LAW IN NEWFOUNDLAND}

Newfoundland is a very large island off the coast of North America, about the same size as the north island of New Zealand. In the first part of the nineteenth century, its principal benefit to Britain was not the land itself, which was not well suited to agriculture, but its proximity to the fisheries off the coast. ${ }^{9}$

7 See for instance the attitudes displayed in $R v$ Powell [1799] NSWKR 7 (Court of Criminal Judicature)

8 See for example BH Mann Neighbors and Strangers: Law and Community in Early Connecticut (University of North Carolina Press, Chapel Hill, 1987); CH Dayton Women Before the Bar: Gender, Law and Society in Connecticut, 1639-1789 (University of North Carolina Press, Chapel Hill, 1995); D Langum Law and Community on the Mexican California Frontier: Anglo-American Expatriates and the Clash of Legal Traditions, 1821-1846 (University of Oklahoma Press, Norman, 1987); P Karsten Between Law and Custom: "High" and "Low" Legal Cultures in the Lands of the British Diaspora, 1600-1900 (Cambridge University Press, Cambridge, 2002); Robert Baker "Creating Order in the Wilderness: Transplanting the English Law to Rupert's Land, 1835-51" (1999) 17 Law and History Review 209; John Pagan Anne Orthwood's Bastard: Sex and Law in Early Virginia (Oxford University Press, New York, 2003).

9 On Newfoundland see Kercher and Young "Informal and Formal Law", above n 2. 
Between 1817 and 1822, when Francis Forbes was Chief Justice of Newfoundland, it was not even a colony. Fishermen sailed to the Grand Banks each summer, using the island for drying their fish. The government discouraged permanent residence and land ownership on Newfoundland. It wanted the fishermen to return to Britain at the end of each season. Despite this official policy, however, they increasingly wintered there from the mid-eighteenth century onwards. What had been a migratory fishery was gradually taken over by resident fishermen. By 1817 Newfoundland had a permanent population of over 43,000. A combination of popular resistance to official policies on land holding and government neglect led to the buying and selling of land on the island. People thought they had good title, and put their money where their beliefs were.

The British policy against permanent residence was reinforced by two statutes governing Newfoundland, one in 1699 and the other in $1775 .{ }^{10}$ Most of the legislation regulated the fishery and the comings and goings of fishermen, but some sections referred to land holdings. The 1699 Act was ambiguous about land though. It distinguished between land used for the fisheries and other land, but did not make clear what the title was in either case. The question of title went to more than land holding: if it was something like fee simple, then the island itself approached the status of a colony. The policy of the individual governors fluctuated between allowing year round residence, and firmly opposing it. Buildings continued to be constructed, some with official approval and many not.

What did the Supreme Court do about these mass breaches of official policies? There was no doubt that the fundamental law to be applied in Newfoundland was that of England: under 32 Geo 3 c 46, s 1 (1792), the Supreme Court was to determine suits at Newfoundland "according to the law of England, as far as the same can be applied". (The same formula was adopted for New South Wales in $1828 .{ }^{11}$ ) Chief Justice Forbes had to find a path between the specific legislation applicable to the island, the common law, the policies of the local governors and British government, and the customary land holding practices of the people of Newfoundland. (The island had no legislature at the time he was in office there.)

This statutory reception of law formula allowed Forbes some flexibility in the application of English law, which he took advantage of in both Newfoundland and, during his later appointment there, as Chief Justice of New South Wales. His general approach was to use the laws of England when they suited the needs of the colony, and to discard them when he felt they were unsuitable. On occasions, he quite explicitly allowed local customs to remain in force even when they breached the laws of England. ${ }^{12}$

10 An Act to Encourage the Trade to Newfoundland 169910 and 11 Wm 3 c 25; Newfoundland Fisheries Act 177515 Geo III c 31.

11 Australian Courts Act 1828 (UK) 9 Geo IV c 83, s 24.

12 See especially Macdonald $v$ Levy, Supreme Court of New South Wales, 8 March 1833 per Burton J, reported in the Sydney Herald (Sydney, 11 March 1833); and see Yonge v Blaikie (1822) 1 Newfoundland 
Francis Forbes resolved the issue of the status of land titles in this most peculiar British possession. The first of these decisions was Williams $v$ Williams $(1818),{ }^{13}$ in which the question concerned the inheritance of land within the fishing area, the land close to the sea. Forbes elevated the island's customary practice into formal law, by holding that the simple customary tenure which passed from person to person was also sound in law. This could not have been the development of the common law through English law's recognition of customs, since that required that the custom had been in force since time immemorial, which meant 1189. Instead Forbes' device was to say that this tenure was an implied term in contracts. As Forbes put it in $R v$ Row, possession and quiet use were the best title to land within the fisheries. ${ }^{14}$ (Some of the land within the fishery was held as permissive occupants of the Crown: the customary title there was good against all but the Crown. ${ }^{15}$ )

There was more to this than customary title: Forbes found in these cases that the 1699 legislation applicable to the island gave title to anyone constructing a building on unoccupied fishery land after 1865. Land built on before then was held on permissive occupancy, unless it had been in continuous occupation since it was first used. If built on before 1685, then abandoned, it could only be held by permissive occupancy after then.

Through statutory interpretation, then, Forbes found that the Royal Instructions denying title to land in the island were contrary to law. It was never simply unlawful to own land on the island, any more than it was directly illegal to live there permanently.

That left title away from the coast (outside the fishery), the very great majority of the island. Forbes squarely faced this question in $R v$ Kough (1819) 1 Newfoundland Law Reports 172. Until then the question had been avoided by Forbes and his predecessors. The Crown, he said, had beneficial title over the island, under the classification of occupation (presumably meaning settlement). The Crown was the source of titles, as in many colonies. Native title (that of the Beothuks) was ignored, as in New South Wales. The assumption was terra nullius. That was not the end of the matter, however.

The Crown brought the action in $R v$ Kough. Forbes held that the statutory doctrine of adverse possession applied in Newfoundland: the statutes were 21 James 1 c 14 and 9 Geo 3 c 16 . Under the former, twenty years' undisturbed and adverse possession of lands by a subject barred the Crown from entering the lands and compelled it to establish a strictly legal title. Under the latter, sixty

Law Reports 277 (Nf'land SC); Norris v Carter (1821), Supreme Court of Judicature, Newfoundland, in Sir Francis Forbes Decisions of the Supreme Court of Judicature in Cases Connected with the Trade and Fisheries of Newfoundland 1817-1821, Mitchell Library, Sydney (ML), A740 at 248.

131 Newfoundland Law Reports 103 (Nf'land SC), but the judgment is only found in Forbes' unreported decisions, ibid.

$14 R$ V Row (1818) 1 Newfoundland Law Reports 126 (Nf'land SC).

15 Hoyles $v$ Bland (1819) 1 Newfoundland Law Reports 160 (Nf'land SC), but see the restriction on the Crown's rights in $R v$ Row, ibid. 
years' undisturbed and adverse possession furnished a subject with complete and perfect title, even against the Crown. As the land in question had been held for over 20 years, the Crown had to prove its title. It was unable to show that it had merely been permissive occupancy. The land was safe against the claims of the Crown, and as a result, much of the land in the town was secure from arbitrary repossession.

The people of Newfoundland had found the security of their titles. Within the fisheries, this was done by Forbes interpreting the statutes in favour of secure title rather than as the Crown had assumed, against it. And in the towns and elsewhere away from the immediate area of the coast, basic English land law applied. The Crown's policy of discouraging settlement while allowing it to continue in fact had at last caught up with it: even the Crown could lose title if it ignored others' occupation of its lands for long enough. The people of Newfoundland now had it on the island's highest judicial authority that it was legal to live permanently there, and to own land there outside the fishery even without a formal Crown grant.

Governor Hamilton referred these decisions to the Crown lawyers in London. To his mortification, they upheld the Chief Justice's view. Newfoundland was no longer merely a seasonal fishery. It was well on the way to becoming an ordinary colony.

Land holding in Newfoundland had been carried on in a customary fashion for very many years before Forbes arrived. Land within the fisheries was passed from person to person, and away from the coast the same applied. The usual conveyances, mortgages and inheritances took place. The people of Newfoundland thought their titles were sound, and spent money buying land and building on it in practical assertion of that belief. This was all despite the British government's formal policy to restrain permanent residence and land holding there. Forbes turned this on its head through a combination of the recognition of these popular customs, the adoption of English statute law and the interpretation of the island's basic legislation in a way contrary to the views of British government. To a large extent, the people of Newfoundland helped to create its most fundamental law, that of the right to own and live on its land.

\section{INFORMAL LAND LAW IN NEW SOUTH WALES}

Even though New South Wales was established as a penal colony, the British government encouraged private land holding from the start. Unlike Newfoundland then, informal titles were not based on official discouragement of land holding.

New South Wales titles were derived from the essentially feudal principle of Crown grants: all land was supposedly held from the Crown. The governors had delegated power to make land grants. Officers were granted land first, followed by emancipated convicts. Until 1831, there was no initial charge for receiving one of these grants. They were, however, conditional on work being done on the land, and on the payment of quit rents. As in Newfoundland, the informality of titles in New South Wales had nothing to do with indigenous land titles. In both colonies the assumption of both officials and the people (with rare exceptions) was what was later called terra nullius. Titles should 
have been clear in New South Wales. As all titles rested on Crown grants, they should have been subject to an easy tracing back to the original grant. That turned out not to be true in practice.

Informal titles in New South Wales derived from both official and popular legal errors. As in Newfoundland, however, the people of New South Wales were so convinced of the legitimacy of these dubious titles that they worked the land, mortgaged it and bought it for what passed for good currency. (The early colony's money was as doubtful as its land titles.)

Conflicts between formal and informal land titles began well before Francis Forbes commenced sitting as the first Chief Justice in New South Wales in 1824. (He left Newfoundland in 1822, and worked in London between then and his next judicial appointment in the penal colony.) In the early years of New South Wales, land had a very different meaning from that in England: it was merely a place to live on or to grow crops. In some cases, parcels of land were sold for less than the value of a horse. $^{16}$

This difference was reflected in the custom of buying and selling land in New South Wales. People passed over the Crown grant documents in return for the price. The transaction was sometimes recorded on the back of the grant document. In 1814, for example, a sharp operator known as Dick the Needle (Samuel Phelps) bought a farm for the price of a mare, a foal and $£ 5$. He was illiterate and so was his seller, Thomas Sanders. Phelps resold the farm to Thomas Jones, but then Sanders reclaimed the land. Sanders said he had only leased it to Phelps and that Phelps thus had no right to sell the freehold to Jones. Only the Crown grant document was available to show who owned the land. Phelps said there had been a written contract of sale when he bought the land, but that it was lost. Nor was the initial sale noted on the back of the Crown grant, as the popular practice sometimes had it. Despite the flimsiness of this chain of title, the civil court under the English barrister, Judge Advocate Ellis Bent, allowed it to stand. ${ }^{17}$ Recognising the dangers of sales based on oral evidence for land titles, the governors had issued orders requiring the writing and registration of contracts to sell land. These were ignored in many cases, as in Sanders $v$ Jones. The colony's Court of Civil Jurisdiction had to mediate between the formal requirements of sales and the popular practice of loose conveyancing. In Sanders $v$ Jones the court decided in favour of popular practices over the governors' orders, by holding the sales valid. Ellis Bent allowed popular custom to be elevated into formal law, just as Forbes had done in Newfoundland. The governors were left to the impotent repetition of orders that land sales contracts were to be in writing and registered.

Uncertainty of titles had official origins as well. When the governor promised to make a grant, the recipient was allowed onto the land in advance of the grant, which became known as permissive occupancy. Some recipients sold on the land before the grant was completed. The governors also

16 On land in the early years of the colony, see Kercher "Resistance to Law under Autocracy", above n 5; and in the years under Forbes as Chief Justice, see Kercher and Young "Informal and Formal Law", above n 2.

17 Sanders $v$ Jones [1814] NSWKR 5 (Court of Civil Jurisdiction). 
allowed permissive occupation by mere verbal authority or by a quick note on applications for building plans. The majority of town land was held in this way. Even when grants were made, official surveying was sometimes inaccurate. Another problem could be traced back to the conditional nature of the grants: when the holder of land breached the conditions of the grant, the grant was revoked and the land given to another under a new Crown grant. As a result, there were sometimes two circulating land grant documents for one piece of land. Furthermore, beginning with the first governor, Arthur Phillip, some of the governors made grants in their own names rather than that of the King. ${ }^{18}$

The most important defect was possession on permissive occupancy. These very loose titles were sold or mortgaged as if they were sound. As noted by Governor Brisbane in 1822: "the general feeling in the colony ... [is] that the smallest scrap of paper containing a promise of grant [is] equivalent, if not superior, to the best title from the Crown". ${ }^{19}$

By the time that $R v$ Cooper (1825) came before the New South Wales Supreme Court, Francis Forbes was sitting as the colony's first Chief Justice. ${ }^{20}$ Cooper had applied for a land grant so that he could build a distillery. The Surveyor General told him that the governor had approved the issue of a grant, and that he could enter the land and commence work. A grant would be made when the surveying was completed. Cooper spent over $£ 2000$ in improving the land before the governor discovered that an error had been made: the land included a stream. As a result, the Crown grant was never issued, and the Attorney General commenced an action against Cooper seeking recovery of the land. This was the colony's first action for intrusion, a proceeding in the nature of trespass that was directed at the Crown recovering land from a subject who was in wrongful occupation. Cooper's defence relied on the actions of the surveyor in authorising his possession. He also contended that he had taken possession of the land "conformably to the universal practice in the colony". Chief Justice Forbes was required to decide between the customary title of the colony and formal English law.

The result would have surprised the people of Newfoundland: in this case Forbes found for the Crown. He held that "grants, to be valid as against the Crown, should be under the great seal and of record ... No grant could be valid that wanted any of the solemnities thus enjoined".

The special jury fruitlessly declared that "Mr. Cooper has obtained possession of the land in question, in the manner hitherto practiced in the colony". To Forbes, these were merely "loose

18 The latter did not result in litigation. It was resolved by a reissue of the grants in Van Diemen's Land, and by colonial legislation validating these informal grants in New South Wales (Limitation of Actions Act 18366 Will IV No 16 (UK)); see CH Currey Sir Francis Forbes (Angus and Robertson, Sydney, 1968) at 482-484.

19 Brisbane to Bathurst, 10 April 1822, Historical Records of Australia: Series I, Governors' Despatches to and From England [HRA], Frederick Watson (ed) (Sydney: Committee of the Commonwealth Parliament, 1914-1925), vol 10 at 630 .

$20 R v$ Cooper [1825] NSWKR 2 (SCNSW). 
usages". He said that the colonial custom could not be formally recognised as part of the common law because it derogated from the law. (It was also centuries short of the required longevity for recognisable customs.)

Forbes reached the same decision in $R v$ Payne in $1830 .{ }^{21}$ This time, the title was also based on permissive occupancy, but the land holder had gained possession through subsequent sales. Forbes held that such title was not good against the Crown, although he did not state its effect between the subjects of the Crown.

This led to a crisis because the great majority of the land in the colony was held informally. Many people were unable to show that their titles derived from a valid Crown grant. In $R v$ West (1831 and 1832), the land in question had been held on permissive occupation for over 20 years, yet the result was the same. There was no reference to the Statute of James on which Forbes had relied in Newfoundland. There, however, the Crown had been unable to show that the land had been held in permissive occupancy. Here that would have been easy. The governors made two errors: they failed to grant the land formally, and they misled the entire community into thinking that they held their lands securely.

Barristers and juries argued repeatedly against the strict application of English law in these New South Wales land cases. In $R v$ Steele (1834) for example, the jurors signed a certificate stating that "if the usage of the colony and the equity and good conscience of the defendant's claim had not been wholly taken from our consideration by the ruling ... we should have unanimously decided, on the merits, in favour of the defendant". ${ }^{22}$ This notion would reappear in legislation, as we are about to see.

Forbes saw the injustice in these cases, despite their conformity to law. In reporting the result in $R v$ Cooper, he recommended to the governor that Cooper should have a grant of the land he occupied, "under such terms, and with such reservations of the right of the water to the public, as to Your Excellency may seem equitable". ${ }^{23}$ The governors of the penal colony had paternalist discretion over many matters. The confirmation of informal land titles became another.

This principle of Crown discretion over land titles took statutory form in the New South Wales Court of Claims Act 1833. ${ }^{24}$ This legislation authorised the creation of the Court of Claims, a

$21 R v$ Payne, Supreme Court of New South Wales, 18 March 1830 per Forbes CJ, reported in the Australian (Sydney, 19 March 1830).

$22 H R A$, above n 19, series 1 vol 18 at 179; $R$ v Steele, 28 October 1834, Supreme Court of New South Wales per Forbes CJ, Dowling and Burton JJ, Sydney Herald (Sydney, 20 October 1834).

23 Forbes to Governor Brisbane, 16 February 1825, Chief Justice's Letter Book, State Records of New South Wales, 4/6651, 24

24 The consolidated Acts of New South Wales gave it this title. Sometimes called the Crown Lands (Claims) Act 4 Will IV No 9 (NSW) was later incorporated in (1835) 5 Will IV No 21(NSW) when the court was established on a more permanent basis. The same problem of uncertain titles occurred in Van Diemen's Land, with the same solution. The Court of Claims there was known as the Caveat Board: Alex C Castles, 
tribunal specifically designed to investigate and report on claims to land that were based on promises of grant from the government. The court's commissioners were to act according to "the real justice and good conscience of the case without regard to legal forms and solemnities". They could take into account that the person concerned had been in undisputed occupation for ten or twenty years. A positive finding meant that the claimants were entitled to treat the land as their property. On receipt of their report however, the governors had discretion whether to issue a formal grant. ${ }^{25}$ This legislation was established at the request of Governor Bourke and on the advice of the Supreme Court judges (Forbes, Dowling and Burton). ${ }^{26}$ The principle would become important in New Zealand.

Forbes acted more strictly in New South Wales than he had in Newfoundland, a puzzle which needs to be solved. ${ }^{27} \mathrm{He}$ had an ambiguous statute to hang onto in Newfoundland, unlike New South Wales, but his attitude in the latter was also much stricter.

Forbes' strictness in land cases was confined to actions concerning the rights of the Crown. In Doe dem Unwin $v$ Salter (1832) the full Court (including Forbes) held that a permissive occupant had sufficient title to eject an intruder by the process of the courts. This was repeatedly confirmed by the court. The customary title of the colony thus had some legal recognition, though not against the Crown.

\section{INFORMAL LAND LAW IN NEW ZEALAND}

Snowden v Baker had many of the characteristics shown in the Newfoundland and New South Wales cases. The popular belief among the European settlers was that titles derived from Māori sales were valid, ${ }^{28}$ Baker would not have spent $£ 1000$ in buying the land otherwise. Despite that, there were official doubts, to say the least, about the legal validity of the title.

Four months before the sale from Snowden to Baker, Governor Gipps of New South Wales issued a New Zealand land proclamation dated 19 January $1840 .{ }^{29}$ It said that the Queen would not

Petrow (ed) Lawless Harvests or God Save the Judges: Van Diemen's Land 1803-55, a Legal History (Australian Scholarly Publishing, North Melbourne, 2007) vol xii at 162-165.

25 Crown Lands Claim Act, ibid, ss 7 and 12. See Enid Campbell "Promises of Land from the Crown: Some Questions of Equity in Colonial Australia" (1994) 13 University of Tasmania Law Review 1; Alex C Castles An Australian Legal History (Law Book Company, Sydney, 1982) at 215-216.

26 See Bourke to Stanley HRA, above n 19, series 1 vol 26 at 177.

27 Some explanations are suggested by Kercher and Young "Informal and Formal Law", above n 2. Another distinction was that there could be no land holding in Newfoundland unless Forbes found a way to legitimise it; there was no such concern in New South Wales where Crown grants were often made and it was simply a matter of enforcing the correct procedure.

28 See P McHugh Maori Magna Carta: New Zealand Law and the Treaty of Waitangi (Oxford University Press, Auckland, 1991) at 78.

29 Apart from the terms of the legislation and of the cases, the following paragraphs are based on Richard Boast Buying the Land, Selling the Land: Governments and Maori Land in the North Island 1865-1921 
acknowledge any titles to land in New Zealand unless derived from a grant in her Majesty's name. At the same time the Crown would recognise previous equitable purchases from the native inhabitants of the colony and would consider absolutely null and void all future purchases. New land titles would only be by Crown grant, while existing ones derived from previous sales by Māori needed confirmation by Crown grants. The purpose of this imposition of the doctrine of pre-emption was to impose control over an increasing number of purchases from Māori . The proclamation referred to the use of commissioners to investigate the pre-existing titles derived from Māori , and caused consternation to the New South Wales business community and to the New Zealand Company which had invested heavily in speculative purchases from Māori chiefs. The first governor in New Zealand, Hobson, later issued similar proclamations, which were followed by the Treaty of Waitangi.

As the plaintiff argued in Snowden v Baker, a governor's proclamation alone could not change the law of titles to land. The New South Wales Court of Claims Act (or Land Claims Act) of $1840^{30}$ settled the matter, replaced in 1841 by the Land Claims Ordinance, very similar legislation passed by the New Zealand legislature, following formal separation of the colonies. Section 2 of the 1841 Ordinance declared and enacted that "all titles to land in the said Colony of New Zealand which are held or claimed by virtue of purchases or pretended purchases gifts or pretended gifts conveyances or pretended conveyances leases or pretended leases agreements or other titles, either mediately or immediately from the chiefs or other individuals or individual of the aboriginal tribes inhabiting the said Colony, and which are not or may not hereafter be allowed by Her Majesty, her heirs or successors, are and the same shall be absolutely null and void". As in New South Wales itself, the governor could appoint commissioners to enquire into the titles, "guided by the real justice and good conscience of the case without regard to legal forms and solemnities" (s 6). The governor alone was to refer cases to the commissioners (s 5), and they were to make recommendations to the governor whether or not to make formal Crown grants. The discretion whether to make the grant was entirely that of the governor (s 6).

As we have seen, the idea of commissioners to investigate the justice of informal claims to land came from the New South Wales Court of Claims Act 1833. In that colony, the commissioners were created to investigate and report on land claims that were based merely on promises of grants from the government. In New Zealand, the 1840 New South Wales Act and 1841 New Zealand Ordinance

(Victoria University Press, Wellington, 2008) at 22-24; see also McHugh, ibid, at 78-79 and 108-109. On the politics of land claims derived from Maori sales, see M Belgrave "Pre-emption, the Treaty of Waitangi and the Politics of Crown Purchase" (1997) 31 New Zealand Journal of History 23. The terms of the proclamation used here are from the judgment of Martin CJ in Snowden v Baker, above n 1. The preamble to (1840) 4 Vict No 7 (NSW) noted that the decision not to recognise titles other than those derived from the Crown had been made in London on 14 August 1839.

30 (1840) 4 Vict No 7 (NSW), given this title by the New South Wales consolidated Acts. It was called the Land Claims Act in New Zealand: see for example In the Matter of Busby, Supreme Court at Auckland per Arney Chief Justice, reported in the Daily Southern Cross (Auckland, 20 April 1860) at 4. 
used the same mechanism to investigate the justice of claims based originally on sales by Māori to Europeans. The aim was to formalise claims to land obtained on "equitable terms" from Māori, and which were not prejudicial to the interests of the Queen's subjects settled in New Zealand (s 2; s 3). The commissioners were to enquire into the price paid to the original Māori owners, and were not to concern themselves with the price paid on subsequent sales (s 5; s 6). On its face, the principal concern, then, was with justice to Māori. Under the 1833 New South Wales Act, there was no concern with Aborigines, but only with the European settlers.

The newspaper reports of the decision in Snowden v Baker are comprehensive. In one issue the Daily Southern Cross $^{31}$ presented the special case stated for the court, which was a detailed account of the parties' arguments. A later issue of the same newspaper ${ }^{32}$ gave the judgment, which included the Chief Justice's detailed summaries of the governor's proclamation and of the relevant legislation. New Zealand was a very new colony in 1844, but if this is typical its newspapers were already providing high quality law reports. Not all colonies were as lucky.

The newspaper reports show that the plaintiff's claim was for the balance of the purchase price. The defendant had paid $£ 500$ on entering into the contract, and then entered into possession of the land. Since that time, he had remained in possession and paid interest on the outstanding balance of the price. The contract stated that the conveyance would take place after the price was fully paid.

Mr Brewer for the plaintiff made a multipronged argument to the court, part of which need not concern us. He first argued that the price was payable even if title could not be shown. This turned on the question of whether payment of the price was a condition precedent for payment or whether it was an independent obligation.

More importantly for us, the plaintiff argued that his promise was to deliver only the title he held, that derived from the natives. That title was valid, he argued, as there was no contention that the purchase from the natives was illegal. The governor's proclamation came before the contract of sale from Snowden to Baker, but it could not make law. Although it was subsequently repeated and clarified by the New South Wales Act of 1840, that legislation was passed after the date of the contract. No legislation could have any retrospective effect on an agreement under seal, the plaintiff argued. At the date of this agreement, May 1840, a title derived from Māori was the only title known in New Zealand. Even if a title derived from the Crown were required under the contract, the defendant had waived his right to that title: he had entered into possession, remaining there and paying interest on the outstanding balance of the price.

The defendant replied that the balance of the price was not payable unless title from the Crown was given. If not, the defendant and possessors in his position could be ousted by the Crown at any time.

31 Daily Southern Cross (Auckland, 16 September 1843) at 3.

32 Daily Southern Cross (Auckland, 27 January 1844) at 2. 
Judgment was delivered by Martin CJ, who announced that he had consulted with the newly arrived Chapman $\mathrm{J}$ before reaching a final decision.

Chief Justice Martin found for the plaintiff; the balance of the price was payable even though the plaintiff's title was not derived from the Crown. He pointed out that the governor's proclamation on 14 January 1840 had indicated her Majesty's willingness to recognise equitable purchases from Māori made before the date of the proclamation. The New South Wales Act which gave effect to the Crown's intention was passed on 4 August 1840, after the date of the contract between the plaintiff and defendant. The Chief Justice held that it was not necessary to decide whether the promise to pay the price was an independent one, that is, one in which the obligation was to pay regardless of the ability to provide the title promised by the other side. Fortunately for us, he decided the matter on a broader basis.

Under the contract, Martin CJ held, the defendant had no right to demand a title based on a Crown grant. The contract was entered into three months after the proclamation, which meant that the defendant was aware of the difficulties with the title. Even after the New South Wales Act came into effect, the defendant took no steps to rescind the contract. His honour rejected the defendant's argument that the enforcement of the promise to pay the price would in effect hold that a title to land not derived from the Crown was valid and sufficient.

The case turned on the interpretation of the awkwardly expressed Land Claims Ordinance 1841. As stated earlier, s 2 declared and enacted that "all titles to land in the said Colony of New Zealand which are held or claimed by virtue of purchases or pretended purchases ... from the ... aboriginal tribes inhabiting the said Colony, and which are not or may not hereafter be allowed by Her Majesty, her heirs or successors, are and the same shall be absolutely null and void". Despite the strength of this legislative statement, Martin CJ interpreted it so that titles such as that held by the plaintiff were contingent, and subject to the pleasure of the Crown. He could find nothing in the legislation to prevent the Queen's subjects from dealing as freely with these titles as with any other class of contingent interests. His honour stated that the proclamation provided differently for purchases made after 14 January 1840: the Crown considered such titles to be absolutely null and void. They would not be confirmed by Crown grant. Although the date of the original purchase from Māori was not known to the court, there was no allegation that it was made after the date of the proclamation. On that basis, the plaintiff had contracted to sell a contingent title.

This decision thus gave some effect to the customary title accepted among the European people of New Zealand. Despite the forbidding language of the legislation, the Chief Justice found a way to validate the sales of titles derived through Māori sales. The settler population clearly thought that such titles had value, and the Chief Justice confirmed that. He could have interpreted the legislation to mean that titles derived from Māori sales were a nullity until confirmed by Crown grant. That interpretation was open to him due to the clear legislative intention to keep discretion over titles entirely in the hands of the governor. Instead, the Chief Justice interpreted the statutory words to provide for contingent titles, more than a nullity, and something which could be sold. 
His honour made clear, however, that the result would not necessarily be the same in cases where the holder of the land under such a contingent title had to prove her or his claim to the land. In such cases, the Chief Justice held, it might be necessary to prove that the title had been allowed by the Crown. He did not go on to consider explicitly the question of whether such titles would be valid against the Crown. The answer to that question seems clear, that such contingent titles were not sound against the Crown. The contingency in such titles was whether the Crown would confirm the title by grant, and it clearly had discretion not to do so. Despite this, the question was litigated in the Busby litigation, mentioned below.

The decision in Snowden v Baker only affected disputes between subjects of the Crown. In those cases, the Chief Justice decided, sales of Māori derived titles were valid in the interval between the initial pre-1840 purchase from Māori and the Crown's decision to allow or disallow the title in question.

The plaintiff in Snowden v Baker was certainly not alone in asserting the validity of titles derived from pre-1840 sales by Māori. As Richard Boast tells us, ${ }^{33}$ those in Snowden's position became a noisy and troublesome pressure group, who wanted their contingent titles confirmed by Crown grants. Some of these claims resulted in litigation which appears in the New Zealand's Lost Cases website. ${ }^{34}$

The best cases of this kind concerned the claims of James Busby. ${ }^{35}$ In these, Busby went beyond the issue in Snowden v Baker. He sought to use his title derived from Māori sales as a direct challenge to Crown grants. In Busby v McKenzie (1855) for instance, Busby unsuccessfully asserted a Māori based title against the holder of a Crown grant. This rich litigation is examined separately in the paper by Fletcher and Elias. ${ }^{36}$

Another case of the same kind was $R v$ Taylor (1849), in which there was an attempt to set aside a Crown grant to one Beattie. Beattie said he had bought the land from Māori owners before the proclamation of Crown sovereignty. His claim was referred to the commissioners under the Land

33 Boast Buying the Land, above n 28, at 24.

34 For the background to some of these cases, see Belgrave, above $\mathrm{n} 28$, at $30 \mathrm{f}$.

35 Busby v McKenzie, Supreme Court Auckland, 8 June 1855 per Martin Chief Justice, "Auckland Civil Minute Book", 1844-1856, Archives New Zealand, Auckland, BBAE 5635/1a at 309-315; and Supreme Court Auckland, 31 October 1855 per Stephen ACJ, reported in the Daily Southern Cross (Auckland, 2 November 1855) at 2; White v Busby, Supreme Court Auckland, 12 September 1859 per Arney CJ, reported in the Daily Southern Cross (Auckland, 30 September 1859) at 2; In the Matter of Busby Supreme Court Auckland, 20 March 1860 per Arney CJ, reported in the Daily Southern Cross (Auckland, 20 April 1860) at

36 See Fletcher and Elias in this volume. 
Claims Ordinance 1841.37 This was one of a number of challenges to the actions of the commissioners, and in this case it led the court to examine the legislation closely. It held that the commissioners were not to make a final decision under the legislation, but merely to make recommendations to the governor. The Crown grant was held valid.

There were several other actions which attempted to challenge Crown grants, some of which also concerned challenges to the actions of the commissioners. $R v$ Clarke (1848) was similar to $R v$ Taylor: the defendant bought the land from Māori owners before the proclamation of sovereignty, the question was referred to the commissioners for report and there was an unsuccessful challenge to the subsequent issue of his Crown grant. ${ }^{38}$ Not all of these challenges were made by rival European claimants to land: in Meurant $v$ Keir (1854), a similar challenge to a Crown grant was made by a Māori plaintiff. ${ }^{39}$

Other challenges to land titles were closer in kind to those made in New South Wales, in that they were based on issues other than titles being derived from Māori. In Scott v Grimstone (1848) for instance, one of the issues in question was the surveying of the property concerned. ${ }^{40}$ Dorset $v$ Bell (1853) concerned the limits on the powers of the commissioners and governors. ${ }^{41} R v$ McDonald (1849) would also have been familiar to those in Sydney. ${ }^{42}$ It concerned a governor's promise to convey land to the New Zealand Company. Buildings were constructed in the belief that the title was sound. The court decided the question in the same way as Forbes CJ had in New South Wales: a promise of a grant did not create an interest in land. Only a formal Crown grant under the Colonial Seal was sufficient. ${ }^{43}$

$37 R v$ Taylor, Supreme Court Auckland, 16 July 1849 per Martin CJ, reported in the New Zealander (Auckland, 19 July 1849) at 3 and supplement at 1. On Taylor see Mark Hickford "Settling some Important Principles of Colonial Law: Three 'Forgotten' Cases of the 1840s" (2004) 35 VUWLR 1.

$38 R v$ Clarke, Supreme Court Auckland, 24 June 1848 per Martin CJ, Chapman J, reported in the Daily Southern Cross (Auckland, 11 March 1848) at 3; (1 July 1848) at 3-4; (8 July 1848) at 3-4; and (15 July 1848) at 2. See also, Hickford, ibid.

39 Meurant v Keir, Supreme Court Auckland, 20 May 1854 per Martin CJ, reported in Daily Southern Cross (Auckland, 23 May 1854) at 2-3; (26 May 1854) at 3; (1 December 1854) at 3; and (23 February 1855) at 3.

40 Scott v Grimstone, Supreme Court Wellington, 20 March 1848 per Chapman J, reported in New Zealand Spectator and Cook's Strait Guardian (Wellington, 25 March 1848) at 3.

41 Dorset v Bell, Supreme Court Wellington, 10 May 1853 per Stephen CJ, reported in New Zealand Spectator and Cook's Strait Guardian (Wellington, 2 April 1853) at 3; (7 May 1853); (11 May 1853); and (25 May 1853).

$42 R v$ McDonald, Supreme Court Wellington, 20 January 1849 per Chapman J, reported in New Zealand Spectator and Cook's Strait Guardian (Wellington, 30 September 1846) at 2.

43 Other land claims cases included Towgood v Barlow, Supreme Court Wellington, 7 May 1867 per Johnston $\mathrm{J}$, reported in the Wellington Independent (Wellington, 9 May 1867) at 3, and 15 June 1867, reported in Wellington Independent (Wellington, 18 June 1867) at 4-5; Taine v Fox, Supreme Court Wellington, 21 


\section{CONCLUSION}

In all three colonies there was a popular belief in the validity of land titles which were doubtful under formal law. In Newfoundland, the title seemed on its face to be a form of squatting. In New South Wales, the most significant of these cases concerned titles based on permissive occupancy. Only in New Zealand was there any link to native title. The other two colonies were also established in the face of very evident native occupation of land, but in the cases discussed here, New Zealand alone had native sales as the basis of the informal popular titles. ${ }^{44}$

The three colonies' land practices also varied in the extent of popular challenges to official law and policies. Newfoundland was most similar to the pig keepers, in that the occupation of land directly contradicted the erratically enforced government policy against permanent settlement. New South Wales land holders in these cases held their land with the permission of the government squatting cases were a separate category in that colony. ${ }^{45}$ The breaches of law and policy in New South Wales discussed here all concerned the ways in which the land was bought and sold, not the fundamental right to occupy it. And in New Zealand, there was no apparent contradiction to official policies. The informal titles derived from the period before which the government sought to prohibit purchases direct from Māori .

In all three colonies the Supreme Courts were required to find a path between popular views about land titles and official law and policy. In all three, there were cases in which some judicial recognition was given to popular titles: the seeming squatters in Newfoundland, the holders under dodgy conveyances in New South Wales, and the holders of land based on Māori sales in New Zealand. Sometimes colonial people made law well before the age of democracy.

September 1858 per Gresson J, reported in the Otago Witness (Otago, 23 October 1858) at 1; Attorney General v Heale and Whitaker, Supreme Court Auckland, 16 September 1846 per Martin CJ, reported in The New Zealander (Auckland, 19 September 1846) at 2, (26 September 1846) at 3; and (28 November 1846) at 1; Te Waka Kawitini v Parker, Supreme Court Napier, 13 May 1869 per Johnston J, reported in Hawke's Bay Herald (Napier, 21 May 1869) at 3, and Te Waka Kawitini v Parker, Supreme Court Napier, 24 November 1869 reported in the Hawke's Bay Herald (Napier, 26 November 1869) at 2; and the fascinating case of McLiver v Macky, Supreme Court Auckland, 23 September 1856 per Stephen ACJ, reported in Daily Southern Cross (Auckland, 12 December 1856) at 3. The latter was decided by Stephen ACJ, brother of the Chief Justice of New South Wales and advocate for the Aboriginal defendants in the important decision in that colony, $R v$ Murrell, Supreme Court of New South Wales, 5 February 1836 per Forbes CJ, reported in the Sydney Herald (Sydney, 8 February 1836). For a full account of this case see the article by David V Williams in this volume.

44 John Batman's attempt to purchase land from the Aborigines in the Port Phillip District of New South Wales was quickly quashed by the governor: see Castles An Australian Legal History, above n 24, at 28-30.

45 See for example Martin v Munn, Supreme Court of New South Wales, 22 and 23 October 1832 per Dowling, reported in the Sydney Gazette (Sydney, 25 October 1832); Bowerman v MacKenzie, Supreme Court of New South Wales, 18 November 1850 per Stephen CJ, reported in the Moreton Bay Courier (Brisbane, 23 November 1850). 
